\title{
Skin Response Subcategory
}

National Cancer Institute

\section{Source}

National Cancer Institute. Skin Response Subcategory. NCI Thesaurus. Code C117678.

A subdivision of skin response data. 